\title{
Physiological Mechanism of Nitrogen Mediating Cotton (Gossypium hirsutum L.) Seedlings Growth under Water-Stress Conditions
}

\author{
Zhigou Zhou $^{1,2}$, Derrick M. Oosterhuis ${ }^{2}$ \\ ${ }^{1}$ Key Laboratory of Crop Physiology \& Ecology in Southern China of Ministry of Agriculture, Nanjing Agricultural University, Nanjing, \\ China; ${ }^{2}$ Department of Crop, Soil, and Environmental Sciences, University of Arkansas, Fayetteville, USA. \\ Email: oosterhu@uark.edu
}

Received April $2^{\text {nd }}, 2012$; revised April 30 ${ }^{\text {th }}, 2012$; accepted May $9^{\text {th }}, 2012$

\begin{abstract}
The objective of this investigation was to study the effects of nitrogen on tolerance to water-stress in cotton (Gossypium hirsutum L.) seedlings. Growth chamber studies with pots of washed sand were carried out in Fayetteville, USA, and Nanjing, Chinawith three water conditions (well-watered, drought-stressed, and waterlogging), and three nitrogen rates, low nitrogen $\left(16 \mathrm{mM}\right.$, approximately $224 \mathrm{mg} \mathrm{N} \cdot 1^{-1}$ water), medium nitrogen $\left(24 \mathrm{mM}\right.$, approximately $448 \mathrm{mg} \mathrm{N} \cdot \mathrm{l}^{-1} \mathrm{wa}$ ter) and high nitrogen (32 mM, approximately $672 \mathrm{mg} \mathrm{N} \cdot \mathrm{l}^{-1}$ water), respectively. The results showed that water-stress treatments reduced plant biomass, $\mathrm{C} / \mathrm{N}$ ratio, root vigor and leaf photosynthesis $(\mathrm{Pn})$. The plant response to water-stress resistance was affected by nitrogen, and was correlated with the activities of antioxidant enzymes. The changes of antioxidant enzymes was the highest in the low nitrogen rate in the drought-stressed and waterlogged cotton seedlings. Malondialdehyde (MDA) content increased significantly in the water-stress treatments, and was the lowest in the low nitrogen rate. There was a significant reduction of $\mathrm{N}$ accumulation under water stress. Low-nitrogen treatmentincreased $\mathrm{C}$ accumulation, while high-nitrogen treatment decreased $\mathrm{N}$ accumulation. Root vigor was decreased by water stress, and was highest in the low-nitrogen rate. After terminating the water stress, $\mathrm{N}$ application promoted root vigor, especially in waterlogged seedlings. The trends of Pn weresimilarto that of root vigor. These results suggested that low $\mathrm{N}$ application may contribute to cotton drought tolerance by enhancing the activity of antioxidant enzymes and consequently decreasing lipid peroxidation, and enhancing root vigor. However, higher $\mathrm{N}$ should be applied to waterlogging-stressed cotton seedlings after terminating waterlogging.
\end{abstract}

Keywords: Cotton Seedling; Nitrogen; Water Deficit; Drought Stress; Waterlogging; Antioxidant Enzyme Activity; Photosynthesis; Root Vigor

\section{Introduction}

Drought or waterlogging during the growing season affects various physiological and biochemical processes of upland cotton, resulting in reduction of growth, final productivity and fiber quality [1]. Hence, it is important to formulate effective strategies to alleviate the detrimental effects of water stress and enhance plant tolerance to drought or waterlogging in cotton plants [2]. Seedling growth is a key determinant stage of productivity in upland cotton, and short-duration water stress occurring during this stage may significantly reduce leaf expansion, photosynthesis, carbon and nitrogen metabolism, and restrain antioxidant capability $[3,4]$, resulting in low yields and poor quality.

Nitrogen is an essential mineral nutrient required in large amounts by plants [5]. Application of $\mathrm{N}$ has been shown to improve tolerance to drough $[6,7]$ and water- logging $[8,9]$. For drought-stressed plants, Halvorson and Reule [6] found that the yield of wheat (Triticumaestivum L.), maize (Zea mays L.) and barley (Hordeum vulgare L.) increased with higher $\mathrm{N}$ supply. In wheat, $\mathrm{N}$ fertilizer increased biomass, grain production and water use efficiency under drought by increasing leaf area index and maintaining leaf area duration [10]. Saneoka et al. [11] found that the malondialdehyde (MDA) content in creeping bentgrass (Agrostis palustris Huds.) leaves was higher in drought-stressed treatments than in the control, but decreased with increased $\mathrm{N}$ supply. It is reported that higher rates of $\mathrm{N}$ contributed to higher drought tolerance by preventing cell membrane damage and enhancing osmoregulation [11]. However, Stroup et al. [12] showed that switchgrass (Panicum virgatum L.) plants grown with higher $\mathrm{N}$ showed a greater reduction in photosynthesis and leaf water potential under drought stress. In winter 
wheat, Shangguan et al. [13] found that water use efficiency decreased more with high-N fertility than in plants in a low-N treatment due to a larger decrease in photosynthetic rate than in transpiration rate. Increasing soil $\mathrm{N}$ supply decreased the growth of pearl millet (Pennisetumglaucum (L.) R.Br.) under soilwater deficit [14].

In recent years, information has been accumulating on plant biochemical, physiological, morphological, anatomical and metabolic responses to waterlogging in wheat, maize and winter rape $[15,16]$. The adverse effects of waterlogging on terrestrial plants are a complex phenomena and appear to vary with genotype, pretreatments, plant developmental stage and the duration and severity of flooding. Such inhibitory effects may occur due to the rapid development of anoxic or hypoxic conditions in waterlogged soils. Considerably low amounts of oxygen in the root zone hampers root respiration resulting in a limited supply of energy required for nutrient uptake and transport [17]. This nutrient deficiency ultimately detrimenttally disturbs a range of physiological processes such as root, stem and leaf growth, stomatal closure, photosynthesis and respiration, chlorosis and necrosis resulting in premature leaf senescence, and increased susceptibility to diseases in plants subjected to waterlogged conditions $[18,19]$. In addition, some oxygen-dependent biochemical substances such as cytochromes oxidasesanddesaturases were damaged. Zaidi et al. [20] showed that the early stages of maize development were the most sensitive to waterlogging. Waterlogging for 6 days caused most of the roots except for some adventitious roots to decompose, and plants were unable to take up the required atmospheric and edaphic nutrients, resulting in leaching and denitrification, and finally in $\mathrm{N}$ deficiency.

Nitrogen supply and use are the most effective regulatory factors in crop growth and yield formation, even under stress condition such as drought and waterlogging. Nitrogen also enhanced sucrose synthase activity in wheat grain under water deficit during grain filling. Application of $\mathrm{N}$ has been reported to partially alleviate the damage of waterlogging in maize, corn and barley plants $[8,21$, 22], and increase the biomass of maize [23]. However, it is not known whether nitrogen supply could pay a similar role in cotton subjected to seedlings waterlogging.

Nitrogn metabolism, protein synthesis, and antioxidant metabolism are important plant growth indicators which related to crop yield formation, which have been reported on drought and waterlogging in the cotton root at the flowering and boll-forming stage [24]. However, information of the effect of $\mathrm{N}$ on physiological changesunder water stressin cotton seedlings is not documented yet. It is still unclear whether $\mathrm{N}$ plays a positive role in alleviating the adverse effects of water-stress on the growth of cotton seedlings. Therefore, the objective of this investigation was to study the effects of $\mathrm{N}$ on water-stress tol- erance in cotton (Gossypium hirsutum L.) seedlings.

\section{Materials and Methods}

A pot experiment was conducted in a growth chamber (Conviron PGR35, Conviron, Winnipeg, Canada) at the University of Arkansas Altheimer Laboratory in Fayetteville, USA. Cotton (Gossypium hirsutum L.) cultivar DPL 444B2R was planted on October 1, 2007. The growth chamber study was repeated at Nanjing Agricultural University in Nanjing, China, using a similar transgenic cotton cultivar NuCOTN33B planted on May 15, 2008. When the cotton seedlings had two true leaves, individual healthy and uniform plants were transplanted into $1-\mathrm{L}$ pots $(1.5-\mathrm{L}$ pots in Nanjing, China) containing washed sand and nutrient solution. In both experiments the growth chambers were set for a 12-h photoperiod, with day/night temperature of $30^{\circ} \mathrm{C} / 20^{\circ} \mathrm{C}$. The experiment was arranged in a completely random design, with three treatments of water management and three rates of applied $\mathrm{N}$ fertilizer. Each treatment had 9 replications where one pot with a single plant represented one replication.

Three water treatments included: 1) a well-watered control (WW), water utilization was $66.7 \mathrm{ml} \cdot$ day $^{-1} \cdot$ plant $^{-1}$; 2) a drought-stressed treatment (DS), the water utilization was $33.3 \mathrm{ml} \cdot$ day $^{-1} \cdot$ plant $^{-1}$; and 3) a waterlogged treatment (WL) with $2-3 \mathrm{~cm}$ water layer in the washed sand surface for 10 days after the seedlings were transplanted into pots. The cotton seedlings were waterlogged when the 5th leaf had emerged, and the seedlings were allowed to recover on the evening of the 10th day with a water regime similar to the well-watered control. Water status was monitored every three days by weighing the pots and then watering the plants accordingly. Three $\mathrm{N}$ rates were used (Table 1), $132.2 \mathrm{mg} \mathrm{N} \cdot$ pot $^{-1}$ (LN: $16 \mathrm{mM}$, approximately $224 \mathrm{mg} \mathrm{N} \cdot 1^{-1}$ water), $246.4 \mathrm{mg} \mathrm{N} \cdot \operatorname{pot}^{-1}$ (MN: 24 $\mathrm{mM}$, approximately $448 \mathrm{mg} \mathrm{N} \cdot \mathrm{l}^{-1}$ water) and $369.6 \mathrm{mg}$ $\mathrm{N} \cdot \operatorname{pot}^{-1}$ (HN: $32 \mathrm{mM}$, approximately $672 \mathrm{mg} \mathrm{N} \cdot 1^{-1}$ water), respectively. The total $\mathrm{N}$ was incorporated into the pots before waterlogging. The other ingredients of the Hoaglands nutrition solutions were the same. When the $5^{\text {th }}, 6^{\text {th }}$ and $7^{\text {th }}$ main-stem leaves of the cotton seedlings had emerged, the second, third and fourth main-stem leaves, respectively, which had been labeled were sampled for analysis.

The net photosynthetic rate (Pn) of labeled leaves were measured with a photosynthesis system (Li-6200, Li-COR Inc., Fayetteville; Li-6400, Li-COR Inc., Nanjing) under $800 \mu \mathrm{mol} \cdot \mathrm{m}^{-2} \cdot \mathrm{s}^{-2}$ light intensity at 9:30-11:00 am. Photosynthesis measurements were taken on the fourth fully expanded main-stem leaf four nodes from the terminal. After measurement of photosynthesis, three seedlings from each treatment were cut at the cotyledonary node. The roots were separated from the sand by washing, and 
Table 1. The concentration of nutrient solutions used for the $\mathbf{N}$ treatments.

\begin{tabular}{cccccccc}
\hline Treatment & $\mathrm{N}$ & $\mathrm{K}$ & $\mathrm{Ca}$ & $\mathrm{Mg}$ & $\mathrm{P}$ & $\mathrm{S}$ & $\mathrm{Fe}$ \\
\hline & $\mathrm{mM}$ & $\mathrm{mM}$ & $\mathrm{mM}$ & $\mathrm{mM}$ & $\mathrm{mM}$ & $\mathrm{mM}$ & $\mu \mathrm{g} \cdot \mathrm{l}^{-1}$ \\
\hline $\mathrm{LN}$ & 16.0 & 4.0 & 1.5 & 1.0 & 2.0 & 1.0 & 5.0 \\
$\mathrm{MN}$ & 24.0 & 4.0 & 1.5 & 1.0 & 2.0 & 1.0 & 5.0 \\
$\mathrm{HN}$ & 32.0 & 4.0 & 1.5 & 1.0 & 2.0 & 1.0 & 5.0 \\
\hline
\end{tabular}

samples of $0.5 \mathrm{~g}$ of white young root were immediately used to assay root activity. The labeled leaveswere stored at $-70^{\circ} \mathrm{C}$ for subsequent enzyme activity analysis. The remaining leaves were collected to measure leaf area with a portable area meter (Li 3000-A, Li-COR Inc., Fayetteville; Li 3100, Li-COR Inc., Nanjing), after which leaves, stem and branches were dried in an oven to a constant weight, and the biomass and the biomass per unit area were determined. After enzyme activity analysis, the soluble sugar and amino acid were measured by utilizing the remaining tagged leaves, and the $\mathrm{C} / \mathrm{N}$ ratio was determined.

For determination of soluble protein content, antioxidant enzyme activity and malondialdehyde(MDA) content, frozen leaves segments $(0.3 \mathrm{~g})$ were crushed into fine power in a mortar in an ice-bath, and $5.0 \mathrm{ml}$ of 0.05 $\mathrm{mol} \cdot \mathrm{L}^{-1}$ phosphate buffer ( $\left.\mathrm{pH} 7.8\right)$ with $1 \%$ polyvinylpyrrolidone (PVP) was used as an extraction buffer. The homogenate was centrifuged at $15,000 \mathrm{rpm}$ for $15 \mathrm{~min}-$ utes at $4^{\circ} \mathrm{C}$, then the liquid was used to measure antioxidant enzyme activities, MDA content and soluble protein content.

Superoxide dismutase (SOD) activity was assayed according the method of Li [25]: One unit of SOD activity was defined as the amount of enzyme required to cause $50 \%$ inhibition of nitro blue tetrazolium (NBT) reduction, measured with a UV-Vis recording spectrophotometer (UV-2401, Shimadzu Corporation, Japan) at $560 \mathrm{~nm}$. Catalase (CAT) activity was determined by potassium permanganate titration. The action mixture contained 2.9 $\mathrm{ml}$ of $50 \mathrm{mM}$ phosphate buffer ( $\mathrm{pH} 7.0$ ), $1.0 \mathrm{ml} 10 \mathrm{mM}$ $\mathrm{H}_{2} \mathrm{O}_{2}$ and $100 \mu \mathrm{l}$ enzyme extract in tubes. Peroxidase (POD) activity was analyzed in $2.9 \mathrm{ml}$ of $0.05 \mathrm{~mol} \cdot \mathrm{L}^{-1}$ phosphate buffer containing $1.0 \mathrm{ml}$ of $0.05 \mathrm{~mol} \cdot \mathrm{L}^{-1}$ guaiacol and $1.0 \mathrm{ml} 2 \% \mathrm{H}_{2} \mathrm{O}_{2}$. The increase in absorbance at $470 \mathrm{~nm}$ was recorded after adding $2.0 \mathrm{ml} 20 \%$ chloroacetic acid. All the above procedures of enzyme extraction were carried out at $0^{\circ} \mathrm{C}-4^{\circ} \mathrm{C}$. Measurement of MDA content was according to the method of Zhang [26] using $500 \mathrm{ml}$ TCA-TBA basic mixture containing $101.25 \mathrm{~g}$ chloroacetic acid (TCA) and $2.5 \mathrm{~g}$ thiobarbituric acid (TBA). $1 \mathrm{ml}$ enzyme extract was injected in $4 \mathrm{ml}$ TCATBA basic mixture. Then the reaction mixture was incubated in boiling water for 20 minutes. After cooling, the reaction mixture was centrifuged at $4000 \times \mathrm{g}$ for $10 \mathrm{~min}$ utes. The absorbance of supernatant liquid was measured at $532 \mathrm{~nm}$ and $600 \mathrm{~nm}$. Measurement of soluble protein content was according to the method of Zhang [26] using $1000 \mathrm{ml} \mathrm{G}-250$ mixture containing $100 \mathrm{mg}$ coomassie brilliant blue G-250, $50 \mathrm{ml}$ 90\% grain alcohol and $100 \mathrm{ml}$ $85 \%(\mathrm{~W} / \mathrm{V})$ phosphoric acid. $1 \mathrm{ml}$ enzyme extract was injected in $5 \mathrm{ml} \mathrm{G}-250$ mixture. The test tubes were shaken for 2 minutes, and the absorbance of the reaction mixture was measured at $595 \mathrm{~nm}$.

Measurement of root vigor was according to the triphenyltetrazolium chloride (TTC) method [25]. The surface moisture on the white young roots was blotted with tissue paper and their fresh weights were measured. Roots with weights $<0.5 \mathrm{~g}$ were placed in tubes, filled with $5 \mathrm{ml}$ of $0.4 \%$ triphenyltetrazolium chloride (TTC), 5 $\mathrm{ml}$ phosphate buffer $\left(0.06 \mathrm{~mol} \cdot \mathrm{L}^{-1}, \mathrm{pH} 7.0\right)$. The tubes were incubated at $37^{\circ} \mathrm{C}$ for up to 3 hours. The chemical reaction was stopped by adding $2 \mathrm{ml}$ of $1 \mathrm{~mol} \cdot \mathrm{L}^{-1}$ sulfuric acid in the tubes. This step was followed by extraction with triphenyl formazan (TPF), which consisted of taking the roots out of the tubes and placing them in a pestlefilled with $3-4 \mathrm{ml}$ of ethyl acetate and a little quartz sand, and grinding. The liquid phase was removed into a test tube, and ethyl acetate was added to the $10 \mathrm{ml}$ level and OD values recorded with a UV-Vis recording spectrophotometer at $485 \mathrm{~nm}$. The OD values were used to calculate equivalent TPF concentrations with which the root activity was determined for each fresh root weight as follows:

Root vigor $\left(\mathrm{TPF} \mu \mathrm{g} \cdot \mathrm{g}^{-1} \mathrm{FW} \cdot \mathrm{hour}^{-1}\right)=\mathrm{TPF}$ reduction $(\mu \mathrm{g}) /$ fresh weight $(\mathrm{g}) /$ time (hour)

All measurements were carried out with three replicates. Statistical analysis was performed using the GLM analysis of variance from the SAS Institute [27].

\section{Results}

\subsection{Growth of Cotton Seedlings}

Plant height of the WW plants was higher than that of the WS and DL treatments, and the DL plants were taller than WS plants (Table 2). The effects of $\mathrm{N}$ application on plant height of the DS treatment wasnon-significant ( $p$ $<0.05$ ), while in WS plants the effect was highest in HN and lowest in LN. Plant height showed a rapid recovery in the WS treatment. Application of N, especially $\mathrm{HN}$ and $\mathrm{MN}$, helped to increase the plant height of the waterlogged WS treatment. The effects of the three water treatments 
Table 2. Growth parameters of cotton seedlings in Fayetteville (2007) and Nanjing (2008).

\begin{tabular}{|c|c|c|c|c|c|c|c|c|c|c|c|}
\hline \multirow{2}{*}{\multicolumn{2}{|c|}{ Water treatments }} & \multirow{3}{*}{$\mathrm{N}$ rates } & \multicolumn{3}{|c|}{ Plant height } & \multicolumn{3}{|c|}{ Biomass } & \multicolumn{3}{|c|}{ Leaf biomass per unit area } \\
\hline & & & DAT 22 & DAT 29 & DAT 36 & DAT 22 & DAT 29 & DAT 36 & DAT 22 & DAT 29 & DAT 36 \\
\hline & & & \multicolumn{3}{|c|}{$\mathrm{cm}$} & \multicolumn{3}{|c|}{$\mathrm{g} \cdot$ seedling $^{-1}$} & \multicolumn{3}{|c|}{$\mathrm{mg} \cdot \mathrm{cm}^{-2}$} \\
\hline \multirow{12}{*}{ Fayetteville } & \multirow{4}{*}{ WW } & $\mathrm{LN}$ & $8.7 b^{1}$ & $15.3 \mathrm{~b}$ & $20.8 b$ & $0.8 \mathrm{~b}$ & $1.5 \mathrm{~b}$ & $2.5 \mathrm{~b}$ & 2 & $5.4 \mathrm{a}$ & $6.3 \mathrm{a}$ \\
\hline & & $\mathrm{MN}$ & $9.7 \mathrm{a}$ & $17.7 \mathrm{a}$ & $23.5 \mathrm{a}$ & $1.3 \mathrm{a}$ & $2.3 \mathrm{a}$ & $3.0 \mathrm{a}$ & -- & $5.4 \mathrm{a}$ & $5.6 \mathrm{~b}$ \\
\hline & & $\mathrm{HN}$ & $9.7 \mathrm{a}$ & $16.7 \mathrm{a}$ & $22.0 \mathrm{a}$ & $0.6 \mathrm{~b}$ & $1.6 \mathrm{~b}$ & $2.7 \mathrm{~b}$ & -- & $5.8 \mathrm{a}$ & $5.9 \mathrm{~b}$ \\
\hline & & Mean & 9.4 & 16.6 & 22.1 & 0.7 & 1.8 & 2.7 & -- & 5.5 & 5.9 \\
\hline & \multirow{4}{*}{ DS } & LN & $10.5 \mathrm{a}$ & $12.3 \mathrm{a}$ & $14.5 \mathrm{a}$ & $0.7 \mathrm{a}$ & $1.2 \mathrm{a}$ & $1.8 \mathrm{a}$ & -- & $5.5 \mathrm{a}$ & $5.9 \mathrm{a}$ \\
\hline & & $\mathrm{MN}$ & $10.2 \mathrm{a}$ & $11.8 \mathrm{a}$ & $14.5 \mathrm{a}$ & $0.6 \mathrm{~b}$ & $1.1 \mathrm{a}$ & $1.5 \mathrm{a}$ & -- & $5.8 \mathrm{a}$ & $5.4 \mathrm{a}$ \\
\hline & & $\mathrm{HN}$ & $9.9 \mathrm{a}$ & $11.0 \mathrm{a}$ & $14.3 \mathrm{a}$ & $0.5 \mathrm{c}$ & $1.1 \mathrm{a}$ & $1.6 \mathrm{a}$ & -- & $5.7 \mathrm{a}$ & $5.7 \mathrm{a}$ \\
\hline & & Mean & 10.2 & 11.7 & 14.4 & 0.6 & 1.1 & 1.6 & -- & 5.7 & 5.7 \\
\hline & \multirow{4}{*}{ WL } & $\mathrm{LN}$ & $11.2 \mathrm{a}$ & 11.6a & $13.1 \mathrm{a}$ & $0.7 \mathrm{a}$ & $1.2 \mathrm{a}$ & $1.6 \mathrm{a}$ & -- & $5.5 \mathrm{c}$ & $5.6 \mathrm{c}$ \\
\hline & & $\mathrm{MN}$ & $9.5 \mathrm{~b}$ & $9.7 \mathrm{~b}$ & $12.3 \mathrm{a}$ & $0.6 \mathrm{~b}$ & $0.8 b$ & $1.6 \mathrm{a}$ & -- & $7.0 \mathrm{a}$ & $7.7 \mathrm{a}$ \\
\hline & & $\mathrm{HN}$ & $7.9 \mathrm{c}$ & $8.3 \mathrm{c}$ & $10.5 \mathrm{~b}$ & $0.5 \mathrm{c}$ & $0.6 \mathrm{~b}$ & $1.3 \mathrm{a}$ & -- & $6.0 \mathrm{~b}$ & $6.4 \mathrm{~b}$ \\
\hline & & Mean & 9.5 & 9.9 & 12.0 & 0.6 & 0.9 & 1.5 & -- & 6.2 & 6.6 \\
\hline \multirow{12}{*}{ Nanjing } & \multirow{4}{*}{ WW } & $\mathrm{LN}$ & $10.5 b$ & $16.7 \mathrm{a}$ & $21.1 \mathrm{~b}$ & $1.2 b$ & $2.3 b$ & $3.2 b$ & -- & $4.4 \mathrm{a}$ & $5.6 \mathrm{a}$ \\
\hline & & $\mathrm{MN}$ & $12.6 \mathrm{a}$ & $18.5 \mathrm{a}$ & $26.3 \mathrm{a}$ & $1.8 \mathrm{a}$ & $3.4 \mathrm{a}$ & $5.3 \mathrm{a}$ & -- & $4.1 \mathrm{a}$ & $4.9 \mathrm{~b}$ \\
\hline & & $\mathrm{HN}$ & $13.1 \mathrm{a}$ & $19.3 \mathrm{a}$ & $27.0 \mathrm{a}$ & $1.8 \mathrm{a}$ & $2.8 \mathrm{~b}$ & $5.0 \mathrm{a}$ & -- & $4.8 \mathrm{a}$ & $5.1 \mathrm{~b}$ \\
\hline & & Mean & 12.1 & 18.2 & 24.8 & 1.6 & 2.8 & 4.5 & -- & 4.4 & 5.2 \\
\hline & \multirow{4}{*}{ DS } & $\mathrm{LN}$ & $9.6 \mathrm{a}$ & $14.7 \mathrm{a}$ & $18.1 \mathrm{a}$ & $0.9 \mathrm{a}$ & $1.8 \mathrm{a}$ & $3.0 \mathrm{~b}$ & -- & $4.9 \mathrm{~b}$ & $4.8 \mathrm{~b}$ \\
\hline & & $\mathrm{MN}$ & $10.1 \mathrm{a}$ & $15.2 \mathrm{a}$ & $17.5 \mathrm{a}$ & $1.2 \mathrm{a}$ & $2.1 \mathrm{a}$ & $3.2 \mathrm{~b}$ & -- & $5.5 \mathrm{a}$ & $5.6 \mathrm{a}$ \\
\hline & & $\mathrm{HN}$ & $10.0 \mathrm{a}$ & $15.8 \mathrm{a}$ & $18.3 \mathrm{a}$ & $0.7 \mathrm{~b}$ & $1.9 \mathrm{a}$ & $4.1 \mathrm{a}$ & -- & $4.7 b$ & $4.5 \mathrm{~b}$ \\
\hline & & Mean & 9.9 & 15.2 & 18 & 0.9 & 1.9 & 3.4 & -- & 5.0 & 5.0 \\
\hline & \multirow{4}{*}{ WL } & $\mathrm{LN}$ & $8.4 \mathrm{c}$ & $10.5 \mathrm{a}$ & $14.1 \mathrm{a}$ & $1.1 \mathrm{a}$ & $1.5 \mathrm{a}$ & $2.1 \mathrm{a}$ & -- & $3.2 b$ & $4.1 \mathrm{~b}$ \\
\hline & & $\mathrm{MN}$ & $11.1 \mathrm{a}$ & $11.0 \mathrm{a}$ & $13.7 \mathrm{a}$ & $1.2 \mathrm{a}$ & $1.7 \mathrm{a}$ & $2.0 \mathrm{a}$ & -- & $4.6 \mathrm{a}$ & $5.3 \mathrm{a}$ \\
\hline & & $\mathrm{HN}$ & $9.9 \mathrm{~b}$ & $8.1 \mathrm{~b}$ & $9.5 \mathrm{~b}$ & $0.5 \mathrm{c}$ & $0.9 \mathrm{~b}$ & $1.5 \mathrm{~b}$ & -- & $3.5 b$ & $4.4 \mathrm{~b}$ \\
\hline & & Mean & 9.8 & 9.9 & 12.4 & 0.9 & 1.4 & 1.9 & -- & 3.8 & 4.6 \\
\hline
\end{tabular}

${ }^{1}$ Means followed by the same letters within the column for each location are not significantly different at $p=0.05 .{ }^{2}$ data not recorded.

on plant biomass was similar to the effects on plant height, with WS the lowest and WW the highest (Table 2). Increasing application of $\mathrm{N}$ helped to increase the biomass per plant in the DS and WL treatments, especially during the water-stressed stage. Specific leaf weight, leaf biomass per unit area, increased $(p<0.05)$ in the WS treatment compared to the WW and DS treatments (Table 2), but there was no difference between WW and DS treatments. Nitrogen application did not change the leaf biomass per unit area of DS, however, increasing application of $\mathrm{N}$ helped increase the leaf biomass per unit area of the waterlogged WS plants.

\subsection{Soluble Protein Content of Cotton Seedlings}

The soluble protein content showed a trend to decrease from the well-watered control WW, to the drought-stressed treatment DS, to the waterlogged-treatment WL (Table 3). The difference of the soluble protein content at DAT 22 was in the order WS $<\mathrm{DS}<\mathrm{WL}$, and there was little difference between WW and DS at DAT 29 and 36. The high nitrogen application $(\mathrm{HN})$ significantly $(p<0.05)$ decreased the soluble protein content, while the low nitrogen level (LN) generally increased the soluble protein content.

\subsection{Antioxidant Enzyme Activity}

There were differences in antioxidant enzymes activities among the three water treatments (Table 4), and these differences changed according to the sampling date. Application of $\mathrm{N}$ played a significant role in adjusting the antioxidant enzymes activities. The SOD activity was at DAT 22in the DSS treatment and lowest in the WLS treatment, and at DAT 29 and DAT 36 the WW was lowest and DS was the highest (Table 4).Application of $\mathrm{N}$ played a significant role in adjusting SOD activity. The HN application significantly $(p<0.05)$ increased SOD activities, but there was no difference of SOD activity between LN and MN except for DSS and WSS at DAT 22. The POD activitywas the opposite to that of SOD at DAT 22, and similar to SOD at DAT 29 and DAT 36 (Table 4). With regard to the effects of $\mathrm{N}$ on adjusting POD activity, LN and MN application signifycantly $(p<0.05)$ increased POD activities at DAT 22, but there was no difference between $\mathrm{LN}$ and $\mathrm{MN}$ in the 
Table 3. Soluble protein content of cotton leaves with different $\mathbf{N}$ rates under different water treatments in Fayetteville (2007) and Nanjing (2008).

\begin{tabular}{|c|c|c|c|c|c|c|c|}
\hline \multirow{3}{*}{$\begin{array}{l}\text { Water } \\
\text { treatments }\end{array}$} & \multirow{3}{*}{$\mathrm{N}$ rates } & \multicolumn{6}{|c|}{ Soluble protein content } \\
\hline & & \multicolumn{3}{|c|}{ Fayetteville } & \multicolumn{3}{|c|}{ Nanjing } \\
\hline & & DAT 22 & DAT 29 & DAT 36 & DAT 22 & DAT 29 & DAT 36 \\
\hline \multirow{4}{*}{ WW } & $\mathrm{LN}$ & $17.7 \mathrm{a}^{1}$ & $19.2 \mathrm{a}$ & $18.7 \mathrm{a}$ & $21.6 \mathrm{a}$ & $24.2 \mathrm{a}$ & $22.7 \mathrm{a}$ \\
\hline & $\mathrm{MN}$ & $17.1 \mathrm{a}$ & $18.0 \mathrm{~b}$ & $18.3 \mathrm{a}$ & $20.8 \mathrm{a}$ & $20.1 b$ & $17.3 b$ \\
\hline & $\mathrm{HN}$ & $12.4 \mathrm{~b}$ & $15.2 \mathrm{c}$ & $14.9 \mathrm{~b}$ & $10.4 \mathrm{~b}$ & $14.1 \mathrm{c}$ & $13.8 \mathrm{c}$ \\
\hline & Mean & 15.7 & 17.5 & 17.3 & 17.6 & 19.5 & 17.9 \\
\hline \multirow{4}{*}{ DS } & $\mathrm{LN}$ & $15.3 \mathrm{a}$ & $17.4 \mathrm{~b}$ & $17.5 \mathrm{a}$ & $14.2 \mathrm{~b}$ & $17.7 \mathrm{~b}$ & $16.2 b$ \\
\hline & $\mathrm{MN}$ & $12.7 \mathrm{ab}$ & $18.8 \mathrm{a}$ & $17.4 \mathrm{a}$ & $16.9 \mathrm{a}$ & $22.1 \mathrm{a}$ & $23.4 \mathrm{a}$ \\
\hline & $\mathrm{HN}$ & $10.5 b$ & $15.5 \mathrm{c}$ & $16.2 \mathrm{a}$ & $8.1 \mathrm{c}$ & $11.4 \mathrm{c}$ & $16.0 \mathrm{~b}$ \\
\hline & Mean & 12.8 & 17.2 & 17.0 & 13.1 & 17.1 & 18.5 \\
\hline \multirow{3}{*}{ WL } & LN & $8.9 \mathrm{a}$ & $16.6 \mathrm{a}$ & $15.0 \mathrm{a}$ & $13.1 \mathrm{a}$ & $18.1 \mathrm{a}$ & $15.6 \mathrm{a}$ \\
\hline & $\mathrm{HN}$ & $8.6 a$ & $11.1 \mathrm{c}$ & $10.4 b$ & $12.8 \mathrm{a}$ & $12.0 \mathrm{~b}$ & $12.1 \mathrm{~b}$ \\
\hline & Mean & 8.8 & 14.1 & 12.2 & 13.2 & 14.2 & 13.3 \\
\hline
\end{tabular}

${ }^{1}$ Mean followed by the same letter are not significantly different at $p=0.05$.

Table 4. Antioxidant enzyme activity of cotton leaves with different $\mathbf{N}$ rates under different water treatments in Fayetteville (2007) and Nanjing (2008).

\begin{tabular}{|c|c|c|c|c|c|c|c|c|c|c|c|}
\hline \multirow{2}{*}{\multicolumn{2}{|c|}{ Water treatments }} & \multirow{3}{*}{$\mathrm{N}$ rates } & \multicolumn{3}{|c|}{ SOD activity } & \multicolumn{3}{|c|}{ POD activity } & \multicolumn{3}{|c|}{ CAT activity } \\
\hline & & & DAT 22 & DAT 29 & DAT 36 & DAT 22 & DAT 29 & DAT 36 & DAT 22 & DAT 29 & DAT 36 \\
\hline & & & \multicolumn{3}{|c|}{ unit $\cdot \mathrm{g}^{-1}$ FreshWeight $\cdot \mathrm{min}^{-1}$} & \multicolumn{3}{|c|}{$\Delta$ OD $470 \cdot \mathrm{g}^{-1}$ FreshWeight $\cdot \mathrm{min}^{-1}$} & \multicolumn{3}{|c|}{$\mu \mathrm{mol} \cdot \mathrm{H}_{2} \mathrm{O}_{2} \cdot \mathrm{g}^{-1}$ FreshWeight $\cdot \mathrm{min}^{-1}$} \\
\hline \multirow{10}{*}{ Fayetteville } & \multirow{3}{*}{ WW } & $\mathrm{LN}$ & $380 b^{1}$ & $327 a$ & $354 b$ & $436 b$ & $424 \mathrm{c}$ & $410 b$ & $1753 b$ & $2144 b$ & $2215 a$ \\
\hline & & $\mathrm{MN}$ & $354 b$ & $324 a$ & $363 b$ & $576 \mathrm{a}$ & $609 b$ & $624 a$ & $2000 \mathrm{a}$ & $2680 \mathrm{a}$ & $2340 \mathrm{a}$ \\
\hline & & $\mathrm{HN}$ & $541 \mathrm{a}$ & $311 \mathrm{a}$ & $449 a$ & $271 \mathrm{c}$ & $761 \mathrm{a}$ & $700 \mathrm{a}$ & $1254 \mathrm{c}$ & $1624 \mathrm{c}$ & $1925 b$ \\
\hline & \multirow{4}{*}{ DS } & $\mathrm{LN}$ & $384 \mathrm{c}$ & $374 b$ & $454 b$ & $396 a$ & $538 b$ & $674 a$ & $1244 \mathrm{a}$ & $2448 \mathrm{a}$ & $2563 a$ \\
\hline & & $\mathrm{MN}$ & $438 b$ & $399 b$ & $446 b$ & $463 a$ & $842 a$ & $663 a$ & $1366 a$ & $2568 \mathrm{a}$ & $2622 a$ \\
\hline & & $\mathrm{HN}$ & $578 \mathrm{a}$ & $532 \mathrm{a}$ & $517 \mathrm{a}$ & $214 b$ & $845 a$ & $769 a$ & $1010 \mathrm{~b}$ & $1781 \mathrm{~b}$ & $2318 b$ \\
\hline & & Mean & 467 & 435 & 472 & 358 & 741 & 702 & 1207 & 2266 & 2501 \\
\hline & \multirow{3}{*}{ WL } & $\mathrm{LN}$ & $279 \mathrm{c}$ & $384 b$ & $369 b$ & $538 \mathrm{a}$ & $292 a$ & $339 a$ & $1299 a$ & $1809 b$ & $1573 a$ \\
\hline & & $\mathrm{HN}$ & $460 \mathrm{a}$ & $471 \mathrm{a}$ & $495 a$ & $365 b$ & $338 \mathrm{a}$ & $350 \mathrm{a}$ & $910 \mathrm{~b}$ & $1336 \mathrm{c}$ & $1215 b$ \\
\hline & & Mean & 364 & 408 & 428 & 485 & 300 & 325 & 1199 & 1785 & 1525 \\
\hline \multirow{10}{*}{ Nanjing } & \multirow{4}{*}{ WW } & $\mathrm{LN}$ & $420 \mathrm{~b}$ & $407 \mathrm{~b}$ & $401 \mathrm{~b}$ & $--^{2}$ & -- & -- & -- & -- & -- \\
\hline & & $\mathrm{MN}$ & $451 \mathrm{~b}$ & $394 \mathrm{~b}$ & $411 \mathrm{~b}$ & -- & -- & -- & -- & -- & -- \\
\hline & & $\mathrm{HN}$ & $679 a$ & $612 \mathrm{a}$ & $542 \mathrm{a}$ & -- & -- & -- & -- & -- & -- \\
\hline & & Mean & 517 & 471 & 451 & -- & -- & -- & -- & -- & -- \\
\hline & \multirow{4}{*}{ DS } & LN & $450 \mathrm{c}$ & $424 b$ & $481 b$ & -- & -- & -- & -- & -- & -- \\
\hline & & $\mathrm{MN}$ & $571 b$ & $461 b$ & $471 b$ & -- & -- & -- & -- & -- & -- \\
\hline & & $\mathrm{HN}$ & $620 \mathrm{a}$ & $612 a$ & $600 \mathrm{a}$ & -- & -- & -- & -- & -- & -- \\
\hline & & Mean & 547 & 499 & 517 & -- & -- & -- & -- & -- & -- \\
\hline & \multirow{2}{*}{ WL } & $\mathrm{LN}$ & $424 b$ & $391 b$ & $411 b$ & -- & -- & -- & -- & -- & -- \\
\hline & & Mean & 469 & 466 & 461 & -- & -- & -- & -- & -- & -- \\
\hline
\end{tabular}

${ }^{1}$ Means followed by the same letter within a location are not significantly different at $p=0.05 .{ }^{2}$ Data not recorded. 
water-stressed experiments. At DAT 29 there was a trend for increased $\mathrm{N}$ to increase POD activity, significant for the WW treatment. At DAT 36 there was little effect of $\mathrm{N}$ on SOD activity. CAT activity was generally higher in the LN and MN treatments (Table 4). The WW and DS treatments were similar and the WS treatment had the lowest CAT activity.

\subsection{MDA Content of Cotton Plants}

In Fayetteville at all three sampling dates the DS treatment had the highest MDA content and the WW treatment had the lowest MDA content (Table 5). In Nanjing, the MDA content was lowest in the WW plants at all three sampling dates, intermediate in DS plants and highest in WL plants (Table 5). Application of N played a significant role in increasing MDA content with increaseing $\mathrm{N}$ rate. Increased $\mathrm{N}$ application resulted in increased MDA content at DAT 22 and 29 for all three water treatments at both locations. At DAT 36, only the Nanjing location showed this same trend. The increase in MDA content of DS and WLS from increased $\mathrm{N}$ rates indicates that $\mathrm{N}$ may reduce the rates of lipid peroxidetion of cotton seedlings (Table 5). However, the change of MDA content was non-significant among the three $\mathrm{N}$ rates at DAT 29 and 36, indicating that the rates of lipid peroxidation mostly resulted from the water treatments, and not from the application rates of $\mathrm{N}$.

\subsection{Root Vigor}

There were significant differences in root vigor among the three water treatments (Table 6). The effects of water treatments on root vigor at DAT 22 were greatest on the $\mathrm{WL}$, intermediate on DS, and least on WW (i.e., WS >
DS $>$ WL). At DAT 29 and 36, the order was DS $>$ WW $>$ WL. Root vigor showed a quicker recovery growth in WL than DS conditions $(p<0.05)$ which exceeded the root vigor of WW in Nanjing. During the water-stress treatment, the effects of $\mathrm{N}$ rates on root vigor were greatest on DS and least on WW. Root vigor decreased significantly $(p<0.05)$ with increasing $\mathrm{N}$ rates. The root vigor of the water-stressed cotton seedlings in $\mathrm{LN}$ was the highest, especially at the DAT 29 and 36, illustrating that only low $\mathrm{N}$ rates may promote the root vigor of water-stressed seedlings.

\subsection{C/N Ratio of Cotton Seedlings}

The effects on $\mathrm{C} / \mathrm{N}$ ratio $(\mathrm{C} / \mathrm{N})$ from different $\mathrm{N}$ rates under different water treatments was similar to that of root vigor (Table 7). There was a significant $(p<0.05)$ reduction of $\mathrm{N}$ accumulation under water-stress. Significant $(p<0.05)$ differences in $\mathrm{C} / \mathrm{N}$ were found among the three $\mathrm{N}$ rates for cotton seedlings. The LN application increased $\mathrm{C}$ accumulation, while the $\mathrm{HN}$ application had the opposite effect. However, the effect on $\mathrm{C} / \mathrm{N}$ ratio from the HN treatment was non-significant $(p<0.05)$ among the three water treatments at DAT 22.

\subsection{Photosynthesis}

Photosynthesis was lower in the two water-stress treatments and generally decreased with sampling date (Table 8). The effects of $\mathrm{N}$ rates on the water-stress treatments was variable. In the WW water regime, Pn decreased signifycantly with increased N. In the DS regime, there was no significant effect of N application at DAT 22 and DAT 36 , but a decrease at DAT 29 in the MN and $\mathrm{HN}$, and in the $\mathrm{WL}$ regime the effect of $\mathrm{N}$ was mostly non-significant.

Table 5. Malondialdehyde (MDA) content of cotton leaves with different $\mathrm{N}$ rates under different water treatments in Fayetteville (2007) and Nanjing (2008).

\begin{tabular}{|c|c|c|c|c|c|c|c|}
\hline \multirow{3}{*}{$\begin{array}{l}\text { Water } \\
\text { treatments }\end{array}$} & \multirow{3}{*}{$\mathrm{N}$ rates } & \multicolumn{6}{|c|}{ MDA content } \\
\hline & & \multicolumn{3}{|c|}{ Fayetteville } & \multicolumn{3}{|c|}{ Nanjing } \\
\hline & & DAT 22 & DAT 29 & DAT 36 & DAT 22 & DAT 29 & DAT 36 \\
\hline & & \multicolumn{6}{|c|}{$\mu \mathrm{mol} \cdot \mathrm{g}^{-1}$ FreshWeight } \\
\hline \multirow{4}{*}{ WW } & $\mathrm{LN}$ & $14.9 b^{1}$ & $16.4 \mathrm{a}$ & $20.9 \mathrm{a}$ & $24.1 \mathrm{~b}$ & $27.4 \mathrm{c}$ & $31.1 \mathrm{~b}$ \\
\hline & $\mathrm{MN}$ & $15.5 \mathrm{~b}$ & $17.1 \mathrm{a}$ & $20.2 \mathrm{a}$ & $25.5 \mathrm{~b}$ & $30.6 \mathrm{~b}$ & $30.3 b$ \\
\hline & $\mathrm{HN}$ & $23.0 \mathrm{a}$ & $17.9 \mathrm{a}$ & $20.0 \mathrm{a}$ & $32.0 \mathrm{a}$ & $34.1 \mathrm{a}$ & $41.1 \mathrm{a}$ \\
\hline & Mean & 17.8 & 17.1 & 20.4 & 27.2 & 30.7 & 34.2 \\
\hline \multirow{4}{*}{ DS } & LN & $24.6 \mathrm{c}$ & $20.4 b$ & $25.6 \mathrm{a}$ & $27.6 \mathrm{c}$ & $28.1 \mathrm{~b}$ & $30.4 \mathrm{c}$ \\
\hline & $\mathrm{MN}$ & $27.6 \mathrm{~b}$ & $25.8 \mathrm{a}$ & $25.1 \mathrm{a}$ & $32.5 b$ & $30.5 b$ & $35.3 b$ \\
\hline & $\mathrm{HN}$ & $30.9 \mathrm{a}$ & $27.2 \mathrm{a}$ & $24.9 \mathrm{a}$ & $41.1 \mathrm{a}$ & $41.1 \mathrm{a}$ & $44.9 \mathrm{a}$ \\
\hline & Mean & 27.7 & 24.5 & 25.2 & 33.7 & 33.2 & 36.9 \\
\hline \multirow{4}{*}{ WL } & LN & $20.2 \mathrm{c}$ & $15.3 \mathrm{a}$ & $19.2 \mathrm{a}$ & $31.0 \mathrm{c}$ & $29.2 \mathrm{c}$ & $35.1 \mathrm{c}$ \\
\hline & $\mathrm{MN}$ & $22.6 b$ & $14.8 \mathrm{a}$ & $18.1 \mathrm{a}$ & $37.5 b$ & $37.1 \mathrm{~b}$ & $44.7 \mathrm{~b}$ \\
\hline & $\mathrm{HN}$ & $26.4 \mathrm{a}$ & $15.6 \mathrm{a}$ & $18.4 \mathrm{a}$ & $48.6 \mathrm{a}$ & $44.5 \mathrm{a}$ & $50.5 \mathrm{a}$ \\
\hline & Mean & 23.1 & 15.3 & 18.6 & 39.0 & 36.9 & 43.4 \\
\hline
\end{tabular}

${ }^{1}$ Means followed by the same letter within a location are not significantly different at $p=0.05$. 

under Water-Stress Conditions

Table 6. Root vigor of cotton seedlings with different $N$ rates under different water treatments in Fayetteville (2007) and Nanjing (2008).

\begin{tabular}{|c|c|c|c|c|c|c|c|}
\hline \multirow{3}{*}{$\begin{array}{c}\text { Water } \\
\text { treatments }\end{array}$} & \multirow{3}{*}{$\mathrm{N}$ rates } & \multicolumn{6}{|c|}{ Root Vigor } \\
\hline & & \multicolumn{3}{|c|}{ Fayetteville } & \multicolumn{3}{|c|}{ Nanjing } \\
\hline & & DAT 22 & DAT 29 & DAT 36 & DAT 22 & DAT 29 & DAT 36 \\
\hline & & \multicolumn{6}{|c|}{$\mu g \cdot g^{-1}$ FreshWeight $\cdot h^{-1}$} \\
\hline \multirow{4}{*}{ WW } & $\mathrm{LN}$ & $1.5 \mathrm{a}^{1}$ & $1.4 \mathrm{a}$ & $1.8 \mathrm{a}$ & $2.4 \mathrm{a}$ & $2.7 \mathrm{a}$ & $3.5 \mathrm{a}$ \\
\hline & $\mathrm{MN}$ & $1.4 \mathrm{a}$ & $0.8 b$ & $1.2 \mathrm{~b}$ & $1.7 \mathrm{~b}$ & $2.0 \mathrm{~b}$ & $2.2 b$ \\
\hline & $\mathrm{HN}$ & $1.4 \mathrm{a}$ & $0.8 b$ & $0.8 \mathrm{c}$ & $1.5 b$ & $1.8 \mathrm{~b}$ & $2.1 b$ \\
\hline & Mean & 1.4 & 1.0 & 1.3 & 1.9 & 2.2 & 2.6 \\
\hline \multirow{4}{*}{ DS } & LN & $1.0 \mathrm{a}$ & $0.9 \mathrm{a}$ & $1.5 \mathrm{a}$ & $1.8 \mathrm{a}$ & $2.2 \mathrm{a}$ & $2.0 \mathrm{a}$ \\
\hline & $\mathrm{MN}$ & $0.8 b$ & $0.7 b$ & $0.9 \mathrm{~b}$ & $1.0 \mathrm{~b}$ & $1.1 \mathrm{~b}$ & $0.9 \mathrm{~b}$ \\
\hline & $\mathrm{HN}$ & $0.6 \mathrm{c}$ & $0.6 b$ & $0.7 \mathrm{c}$ & $0.8 \mathrm{~b}$ & $1.2 \mathrm{~b}$ & $1.1 \mathrm{~b}$ \\
\hline & Mean & 0.8 & 0.7 & 1.0 & 1.2 & 1.5 & 1.3 \\
\hline \multirow{4}{*}{ WL } & LN & $0.7 \mathrm{a}$ & $2.8 \mathrm{a}$ & $2.1 \mathrm{a}$ & $1.6 \mathrm{a}$ & $2.4 \mathrm{a}$ & $2.0 \mathrm{a}$ \\
\hline & $\mathrm{MN}$ & $0.6 \mathrm{ab}$ & $1.9 \mathrm{~b}$ & $1.6 \mathrm{~b}$ & $0.7 b$ & $1.2 \mathrm{~b}$ & $1.4 \mathrm{~b}$ \\
\hline & $\mathrm{HN}$ & $0.5 b$ & $1.4 \mathrm{c}$ & $1.0 \mathrm{c}$ & $0.7 b$ & $1.4 \mathrm{~b}$ & $1.2 b$ \\
\hline & Mean & 0.6 & 2.1 & 1.6 & 1.0 & 1.7 & 1.5 \\
\hline
\end{tabular}

${ }^{1}$ Means followed by the same letter within a location are not significantly different at $p=0.05$.

Table 7. $\mathrm{C} / \mathrm{N}$ ratio of cotton seedlings with different $\mathrm{N}$ rates under different water treatments in Fayetteville (2007) and Nanjing (2008).

\begin{tabular}{|c|c|c|c|c|c|c|c|}
\hline \multirow{3}{*}{$\begin{array}{c}\text { Water } \\
\text { treatments }\end{array}$} & \multirow{3}{*}{$\mathrm{N}$ rates } & \multicolumn{6}{|c|}{ MDA content } \\
\hline & & \multicolumn{3}{|c|}{ Fayetteville } & \multicolumn{3}{|c|}{ Nanjing } \\
\hline & & DAT 22 & DAT 29 & DAT 36 & DAT 22 & DAT 29 & DAT 36 \\
\hline \multirow{4}{*}{ WW } & $\mathrm{LN}$ & $1.7 \mathrm{a}^{1}$ & $1.4 \mathrm{a}$ & $1.6 \mathrm{a}$ & $1.8 \mathrm{a}$ & $1.7 \mathrm{a}$ & $1.7 \mathrm{a}$ \\
\hline & $\mathrm{MN}$ & $1.4 \mathrm{~b}$ & $0.9 \mathrm{~b}$ & $1.1 \mathrm{~b}$ & $1.3 \mathrm{~b}$ & $1.2 \mathrm{~b}$ & $1.2 \mathrm{~b}$ \\
\hline & $\mathrm{HN}$ & $1.0 \mathrm{c}$ & $0.8 \mathrm{~b}$ & $0.8 \mathrm{c}$ & $1.3 b$ & $1.0 \mathrm{~b}$ & $1.2 \mathrm{~b}$ \\
\hline & Mean & 1.4 & 1.0 & 1.2 & 1.5 & 1.3 & 1.4 \\
\hline \multirow{4}{*}{ DS } & $\mathrm{LN}$ & $1.5 \mathrm{a}$ & $0.9 \mathrm{a}$ & $1.2 \mathrm{a}$ & $1.9 \mathrm{a}$ & $1.8 \mathrm{a}$ & $1.9 \mathrm{a}$ \\
\hline & $\mathrm{MN}$ & $0.9 \mathrm{~b}$ & $0.7 b$ & $0.9 \mathrm{~b}$ & $1.5 \mathrm{~b}$ & $1.2 b$ & $1.3 \mathrm{~b}$ \\
\hline & $\mathrm{HN}$ & $0.7 \mathrm{c}$ & $0.6 \mathrm{c}$ & $0.8 b$ & $1.3 b$ & $1.3 b$ & $1.5 \mathrm{~b}$ \\
\hline & Mean & 1.0 & 0.7 & 1.0 & 1.6 & 1.4 & 1.6 \\
\hline \multirow{4}{*}{ WL } & $\mathrm{LN}$ & $0.7 \mathrm{a}$ & $2.2 \mathrm{a}$ & $2.1 \mathrm{a}$ & $1.2 \mathrm{a}$ & $1.4 \mathrm{a}$ & $1.5 \mathrm{a}$ \\
\hline & $\mathrm{MN}$ & $0.6 \mathrm{ab}$ & $1.9 \mathrm{a}$ & $1.6 \mathrm{~b}$ & $0.7 b$ & $0.9 \mathrm{~b}$ & $1.1 \mathrm{~b}$ \\
\hline & $\mathrm{HN}$ & $0.5 b$ & $1.4 \mathrm{~b}$ & $1.0 \mathrm{c}$ & $0.8 b$ & $0.9 \mathrm{~b}$ & $0.9 b$ \\
\hline & Mean & 0.6 & 1.9 & 1.6 & 0.9 & 1.1 & 1.2 \\
\hline
\end{tabular}

${ }^{1}$ Means followed by the same letter within a location are not significantly different at $p=0.05$.

Table 8. Photosynthesis (Pn) of cotton seedlings with different $\mathbf{N}$ rates under different water treatments in Fayetteville (2007) and Nanjing (2008).

\begin{tabular}{|c|c|c|c|c|c|c|c|}
\hline \multirow{3}{*}{$\begin{array}{c}\text { Water } \\
\text { treatments }\end{array}$} & \multirow{3}{*}{$\mathrm{N}$ rates } & \multicolumn{6}{|c|}{$\mathrm{Pn}$} \\
\hline & & \multicolumn{3}{|c|}{ Fayetteville } & \multicolumn{3}{|c|}{ Nanjing } \\
\hline & & DAT 22 & DAT 29 & DAT 36 & DAT 22 & DAT 29 & DAT 36 \\
\hline & & \multicolumn{6}{|c|}{$\mu \mathrm{mol} \mathrm{CO} \cdot \mathrm{m}^{-2} \cdot \mathrm{s}^{-2}$} \\
\hline \multirow{4}{*}{ WW } & $\mathrm{LN}$ & $9.9 \mathrm{a}^{1}$ & $9.9 \mathrm{a}$ & $8.5 \mathrm{a}$ & $14.5 \mathrm{a}$ & $15.6 \mathrm{a}$ & $14.4 \mathrm{a}$ \\
\hline & $\mathrm{MN}$ & $9.8 \mathrm{a}$ & $9.4 \mathrm{ab}$ & $6.0 \mathrm{~b}$ & $13.5 \mathrm{a}$ & $12.4 \mathrm{~b}$ & $11.5 b$ \\
\hline & $\mathrm{HN}$ & $8.2 b$ & $8.9 b$ & $5.4 \mathrm{c}$ & $10.1 \mathrm{~b}$ & $10.0 \mathrm{c}$ & $10.1 \mathrm{~b}$ \\
\hline & Mean & 9.3 & 9.4 & 6.6 & 12.7 & 12.7 & 12 \\
\hline \multirow{4}{*}{ DS } & LN & $7.4 \mathrm{a}$ & $6.0 \mathrm{a}$ & $4.1 \mathrm{a}$ & $11.2 \mathrm{a}$ & $12.7 \mathrm{a}$ & $10.7 \mathrm{a}$ \\
\hline & $\mathrm{MN}$ & $7.5 \mathrm{a}$ & $5.7 \mathrm{ab}$ & $4.4 \mathrm{a}$ & $10.7 \mathrm{a}$ & $10.1 b$ & $9.6 \mathrm{a}$ \\
\hline & $\mathrm{HN}$ & $7.4 \mathrm{a}$ & $5.1 \mathrm{~b}$ & $3.8 \mathrm{a}$ & $11.4 \mathrm{a}$ & $10.0 \mathrm{~b}$ & $9.1 \mathrm{a}$ \\
\hline & Mean & 7.4 & 5.6 & 4.1 & 11.0 & 10.9 & 9.8 \\
\hline \multirow{4}{*}{ WL } & $\mathrm{LN}$ & $7.6 \mathrm{a}$ & $8.1 \mathrm{a}$ & $6.1 \mathrm{c}$ & $9.6 \mathrm{a}$ & $9.0 \mathrm{a}$ & $8.3 \mathrm{a}$ \\
\hline & $\mathrm{MN}$ & $6.4 \mathrm{~b}$ & $8.0 \mathrm{a}$ & $7.3 b$ & $8.9 \mathrm{a}$ & $9.5 \mathrm{a}$ & $8.0 \mathrm{a}$ \\
\hline & $\mathrm{HN}$ & $6.9 b$ & $8.7 \mathrm{a}$ & $8.6 \mathrm{a}$ & $9.1 \mathrm{a}$ & $9.1 \mathrm{a}$ & $8.6 \mathrm{a}$ \\
\hline & Mean & 7.0 & 8.3 & 7.3 & 9.2 & 9.2 & 8.3 \\
\hline
\end{tabular}

${ }^{1}$ Means followed by the same letter within a location are not significantly different at $p=0.05$. 


\section{Discussion}

Plants respond to drought and waterlogging in different ways, such as increasing the root-shoot ratio and carbon metabolization, to maintain the water balance in plants $[13,28,29]$. The present experiments indicate that the physiological reactions were associated with decreases in plant biomass, $\mathrm{C} / \mathrm{N}$ ratio and the biomass per unit leaf area under conditions of drought and waterlogging. Waterlogging at the seedling stage has been shown to result in significant accumulation of leaf malondialdehyde and ethylene production and reduction of leaf photosynthetic rate in rape plants [16]. It has been reported $[19,30]$ that water logging and plant senescence were associated with the degradation of chlorophyll, the accumulation of malondialdehyde, ethylene production, the decrease of SOD and CAT activities, and root oxidizability. In our study, exposure to drought and waterlogging caused increased MDA, decreased photosynthesis that resulted in premature senescence and the plants became significantly damaged. The inhibition of physiological functions of plants caused by drought and waterlogging leads to decreases in plant growth and photosynthesis and consequently, to smaller cotton yields.

Numerous studies have shown that $\mathrm{N}$ can improve plant tolerance to drought and waterlogging $[8,11,13$, $28,29]$. The present experiments indicated that the severity of the effect of drought and waterlogging on cotton was found to depend upon the application $\mathrm{N}$ rate. Suitable $\mathrm{N}$ fertilizer application at the seedling stage could alleviate the plant damage caused by drought and waterlogging. However, high $\mathrm{N}$ application increased the extent of damage caused by drought or waterlogging, which is similar to the effects on wheat grown in waterlogged soil [29]. In our study, application of low rates of $\mathrm{N}$ were beneficial in increasing $\mathrm{C}$ accumulation for both wellwatered and water-stressed conditions, while high rates of $\mathrm{N}$ had the opposite effect. Water deficit and waterlogging $[31,32,33]$ stress have been reported to trigger increased radicals and reactive oxygen species (ROS; $\mathrm{O}_{2}^{-}$, $\mathrm{O}_{2}, \mathrm{H}_{2} \mathrm{O}_{2}, \mathrm{OH}^{-}$) formation in plants, which affects plant metabolism in a variety of ways and results in cellular damage. Application of $\mathrm{N}$ may affect antioxidant enzymes activity, for example, the activities of SOD, POD, $\mathrm{CAT}$ and soluble protein content in the ear leaf of maize were higher in $\mathrm{N}$-applied treatment than in a $\mathrm{N}$-unapplied treatment [34]. In our investigation, application of $\mathrm{N}$ decreased the activities of peroxidase (POD) and catalase (CAT) of cotton seedlings, but increased superoxide dismutase (SOD) activity. The normal rates of the activities of antioxidant enzymes were highest in the low-N rate condition in the waterlogged and drought stress treatments.
Cell membrane stability has been shown to be affected by lipid peroxidation caused by ROS under stress conditions [35]. In our study, lipid peroxidation evaluated by the MDA content in root tissue, was shown to increase under water stress (Table 5). MDA content has been reported to decrease with increased $\mathrm{N}$ in the leaf of water-stressed Agostispalvitris plants [11], and our study showed a similar response (Table 5).

Root vigor is recognized as a reliable and sensitive indicator to evaluate drought [36] and waterlogging resistance. Various researchers have suggested that root vigor was determined by relative enzyme activity, and that appropriate $\mathrm{N}$ rates enhanced root growth [8,37-39]. In our study, drought and waterlogging decreased root vigor during the water-stress period, but the waterloggingstressed root exhibited a quicker recovery in growth after waterlogging was terminated, such that the root vigor in the water-logged treatment WL was higher than that of well-watered control WW (Table 6). The root vigor of LN was the highest among the three $\mathrm{N}$ rates (Table 6).

The extent to which photosynthetic capability is maintained during water-stress plays an important role in plant's acclimation to dry [40] and flooded [41] environments. Although the root and shoot systems are very interdependent and the roots are the source of water and all inorganic nutrients for shoots, the trends in net photosynthetic rate were not the same as that of root vigor (Table 8). Under the well-watered condition (WW), Pn was significantly decreased by higher $\mathrm{N}$ rates, however, higher rates of $\mathrm{N}$ tended to increase Pn after terminating the waterlogging (WL at DAT 36) underwaterlogging conditions (WL), which indicated that more $\mathrm{N}$ was beneficial for a quicker recovery growth of the previously waterlogged-stressed DL seedlings.

Overall, the study showed that while cotton growth (biomass, $\mathrm{C} / \mathrm{N}$ ratio, root vigor and photosynthesis) decreased under water stress (deficit or excess), alleviation of water stress damage may be accomplished by applying available $\mathrm{N}$ fertilizers. Tolerance and recovery from water stress in cotton seedlings was improved under low $\mathrm{N}$ application through altered antioxidant enzyme activity and decreased lipid peroxidation.

\section{Conclusions}

To date, there are few reports on the influence of $\mathrm{N}$ rates on the metabolism of cotton seedlings exposed to water stress. This study showed that $\mathrm{N}$ was involved in physiological functions in cotton seedling under conditions of water-stress. We have identified several significant nitrogen-controlled processes when the cotton seedlings were exposed to water-stress, and showed that application of $\mathrm{N}$ may help to improve the tolerance and recovery growth of water-stressed cotton seedlings. This investi- 
gation suggested that $224 \mathrm{mg} \mathrm{N} \cdot \mathrm{l}^{-1}$ waters likely to be the best rate forcotton seedlings growth under drought and waterlogging, and that more $\mathrm{N}$ should be supplied to waterlogging seedlings after relief of the waterlogging.

Drought and waterlogging from global warming and environment pollution and improper use of $\mathrm{N}$ will be of greater concern in the future. Thus, it will be important to understand the effects on physiological processes under water stress. However, it is necessary to confirm these plant seedling responses obtained from pot experiments in field environments. Experiments should also investigate short to long-term responses and acclimation of cotton after alleviation of water-stress. The results of this research could be used in the future for designing $\mathrm{N}$ management of cotton plants to enhance their resistance to waterstress.

\section{Acknowledgements}

This work was funded by the University of Arkansas, Cotton Physiology Laboratory, Department of Crop, Soil and Environmental Sciences, and the Nanjing University, Laboratory of Crop Physiology and Ecology, Southern China Ministry of Agriculture.

\section{REFERENCES}

[1] P. J. Kramer and J. S. Boyer, "Water Relations of Plants and Soils," Academic Press, San Diego, 1995.

[2] D. A. Loka, D. M. Oosterhuis and G. Ritchie, "Water Stress in Cotton," In: D. M. Oosterhuis, Ed., Stress Physiology in Cotton, Cotton Foundation, Memphis, 2011, pp. 37-72.

[3] R. A. Ball, D. M. Oosterhuis and A. Mauromoustakos, "Growth Dynamics of the Cotton Plant during WaterDeficit Stress," Agronomy Journal, Vol. 86, No. 5, 1994, pp. 788-795. doi:10.2134/agronj1994.00021962008600050008x

[4] S. Ennahli and H. Earl, "Physiological Limitation to Photosynthetic Carbon Assimilation in Cotton under Water Stress," Crop Science, Vol. 45, No. 6, 2005, pp. 2374-2382. doi:10.2135/cropsci2005.0147

[5] H. Marschner, "Mineral Nutrition of Higher Plants," Academic Press, London, 1986, pp. 197-218.

[6] A. D. Halvorson and C. A. Reule, "Nitrogen Fertilizer Requirements in an Annual Dryland Cropping System," Agronomy Journal, Vol. 86, No. 2, 1994, pp. 315-318. doi:10.2134/agronj1994.00021962008600020020x

[7] D. N. Fife and E. K. S. Nambiar, "Changes in the Canopy and Growth of Pinussraiata in Response to Nitrogen Supply," Forest Ecology and Management, Vol. 93, No. 1-2, 1997, pp. 137-152. doi:10.1016/S0378-1127(96)03917-5

[8] M. C. Drew, E. J. Sisworo and L. R. Saker, “Alleviation of Waterlogging Damage to Young Barley Plants by Application of Nitrate and a Synthetic Cytokinin, and Comparison between the Effects of Waterlogging, Nitrogen Deficiency, and Root Excision," New Phytologist, Vol. 82,
No. 2, 1979, pp. 315-329.

doi:10.1111/j.1469-8137.1979.tb02657.x

[9] M. Ashraf and Habib-ur-Rehman, "Interactive Effects of Nitrate and Long-Term Waterlogging on Growth, Water Relations, and Gaseous Exchange Properties of Maize," Plant Science, Vol. 144, No. 1, 1999, pp. 35-43. doi:10.1016/S0168-9452(99)00055-2

[10] K. Latiri-Souki, S. Nortcliff and D. W. Lawlor, "Nitrogen Fertilizer Can Increase Dry Matter, Grain Production and Radiation and Water Use Efficiencies for Durum Wheat under Semi-Arid Conditions," European Journal of Agronomy, Vol. 9, No. 1, 1998, pp. 21-34. doi:10.1016/S1161-0301(98)00022-7

[11] H. Saneoka, R. E. A. Moghaieb, G. S. Premachandra and K. Fujita, "Nitrogen Nutrition and Water Stress Effects on Cell Membrane Stability and Leaf Water Relations in Agostis palustris Huds.," Environmental and Experimental Botany, Vol. 52, No. 2, 2004, pp. 131-138. doi:10.1016/j.envexpbot.2004.01.011

[12] J. A. Stroup, M. A. Sanderson, J. P. Muir, M. J. McFarland and R. L. Read, "Comparison of Growth and Performance in Upland and Lowland Switchgrass Types to Water and Nitrogen Stress," Bioresource Technology, Vol. 86, No. 1, 2003, pp. 65-72. doi:10.1016/S0960-8524(02)00102-5

[13] Z. P. Shangguan, M. A. Shao and J. Dyckmans, "Nitrogen Nutrition and Water Stress Effects on Leaf Photosynthetic Gas Exchange and Water Use Efficiency in Winter Wheat," Environmental and Experimental Botany, Vol. 44, No. 2, 2000, pp. 141-149. doi:10.1016/S0098-8472(00)00064-2

[14] M. Ashraf, M. Shabaz and M. Y. Ashraf, "Influence of Nitrogen Supply and Water Stress on Growth and Nitrogen, Phosphorus, Potassium and Calcium Contents in Pearl Millet," Biologia Plantarum, Vol. 44, No. 3, 2001, pp. 459462. doi:10.1023/A:1012400422848

[15] Y. Mano, M. Muraki, T. Komatsu, M. Fujimori, F. Akiyama and T. Takamizo, "Varietal Difference in Pre-Germination Flooding Tolerance and Waterlogging Tolerance at the Seedling Stage in Maize Inbred Lines," Japanese Journal of Crop Science, Vol. 71, No. 3, 2002, pp. 361-367. doi:10.1626/jcs.71.361

[16] W. Zhou, D. Zhao and X. Lin, "Effects of Waterlogging on Nitrogen Accumulation and Alleviation of Waterlogging Damage by Application of Nitrogen Fertilizer and Mixtalol in Winter Rape (Brassica napus L.)," Plant Growth Regulation, Vol. 16, No. 1, 1997, pp. 47-53. doi:10.1007/PL00006974

[17] G. Boru, T. Vantoai, J. Alves, D. Hua and M. Knee, "Response of Soybean to Oxygen Deficiency and Elevated Root-Zone Carbon Dioxide Concentration," Annals of Botany, Vol. 91, No. 4, 2003, pp. 447-453. doi: $10.1093 / \mathrm{aob} / \mathrm{mcg} 040$

[18] C. T. Liao and C. H. Lin, "Physiological Adaptation of Crop Plants to Flooding Stress," Proceedings of the National Science Council Republic of China (B), Vol. 25, No. 3, 2001, pp. 148-157.

[19] M. P. Bange, S. P. Milroy and P. Thongbai, "Growth and Yield of Cotton in Response to Waterlogging," Field 
Crop Research, Vol. 88, No. 2-3, 2004, pp. 129-142. doi:10.1016/j.fcr.2003.12.002

[20] P. H. Zaidi, G. Srinivasan and N. N. Singh, "Increasing Crop-Water Productivity through Genetic Improvement for Tolerance to Water Stresses in Maize (Zea mays L.)," In: T. Fischer, et al., Eds., New Directions for a Diverse Planet, Proceedings 4th International Crop Science Congress, Brisbane, 26 September-1 October 2004.

[21] J. Shalhevet and P. J. Zwerman, "Nitrogen Response of Corn under Variable Conditions of Drainage-A Lysimeter Study," Soil Science, Vol. 93, No. 3, 1962, pp. 172-182. doi:10.1097/00010694-196203000-00004

[22] G. P. Chen, "Alleviation of Waterlogging Damage to Maize Plants by the Application of Nitrogen Fertilizers," Acta Agriculture of North China, Vol. 4, 1989, pp. 26-31.

[23] W. S. Meyer, H. D. Barrs, A. R. Mosier and N. L. Schaefer, "Response of Maize to Three Short-Term Periods of Waterlogging at High and Low Nitrogen Levels on Undisturbed and Repacked Soil," Irrigation Science, Vol. 8, No. 4, 1987, pp. 257-272. doi:10.1007/BF00257510

[24] R. X. Liu, Z. G. Zhou, W. Q. Guo, B. L. Chen and D. M. Oosterhuis, "Effects of N Fertilization on Root Development and Activity of Water-Stressed Cotton (Gossypium hirsutum L.) Plants," Agricultural Water Management, Vol. 95, No. 11, 2008, pp. 1261-1270. doi:10.1016/j.agwat.2008.05.002

[25] H. S. Li, "Principles and Techniques of Plant Physiological Experiment," Higher Education Press, Beijing, 2000, pp. 119-120.

[26] X. Z. Zhang, "Crop Physiology Research Methods," China Agricultural Press, Beijing, 1992, pp. 131-207.

[27] SAS Institute Inc., "SAS/STAT Guide for Personal Computers," Version 7, SAS Institute Inc., Cary, 1999.

[28] B. R. Huang, J. W. Johoson, S. Nesmith and D. C. Bridges, "Growth, Physiological and Anatomical Response of Two Wheat Genotypes to Waterlogging and Nutrient Supply," Journal of Experimental Botany, Vol. 45, No. 2, 1994, pp. 193-202. doi:10.1093/jxb/45.2.193

[29] D. Jiang, X. Fan, T. Dai and W. Cao, "Nitrogen Fertiliser Rate and Post-Anthesis Waterlogging Effects on Carbohydrate and Nitrogen Dynamics in Wheat," Plant and Soil, Vol. 304, No. 1-2, 2008, pp. 301-314. doi:10.1007/s11104-008-9556-X

[30] Z. F. Lin, S. S. Li, G. Z. Lin, G. C. Sun and J. Y. Guo, "Superoxide Dismutase Activity and Lipid Peroxidation in Relation to Senescence of Rice Leaves," Journal of Integrative Plant Biology, Vol. 26, No. 6, 1984, pp. 605-615.

[31] B. Yan, Q. Dai, X. Liu, S. Huang and Z. Wang, "Flood-
ing-Induced Membrane Damage, Lipid Oxidation and Activated Oxygen Generation in Corn Leaves," Plant and Soil, Vol. 179, No. 2, 1996, pp. 261-268. doi:10.1007/BF00009336

[32] R. K. Sairam, P. S. Deshmukh and D. C. Saxena, "Role of Antioxidant Systemsin Wheat Genotypes Tolerance to Water Stress," Biologia Plantarum, Vol. 41, No. 3, 1998, pp. 387-394. doi:10.1023/A:1001898310321

[33] C. Olivella, C. Biel, M. Vendrell and R. Save, "Hormonal and Physiological Responses of Gerbera jamesonii to Flooding Stress," HortScience, Vol. 35, No. 2, 2000, pp. 222-225.

[34] J. W. Zhang, K. J. Wang, C. H. Hu, S. T. Dong and P. Liu, "Effects of Different Nitrogen Application Stages on Forage Nutritive Value of Summer Maize," Scientia Agricultura Sinica, Vol. 35, No. 11, 2002, pp. 1337-1342.

[35] C. Sudhakar, A. Lakshmi and S. Giridarrakumar, "Changes in the Antioxidant Enzyme Efficacy in Two High Yielding Genotypes Of Mulberry (Morus alba L.) under $\mathrm{NaCl}$ Salinity," Plant Science, Vol. 161, No. 3, 2001, pp. 613619. doi:10.1016/S0168-9452(01)00450-2

[36] H. F. Wang, Y. H. Zhu and H. J. Sun, "Determination of Drought Tolerance Using Root Activities in Robinapseudoacacia 'Idaho' Transformed with mtl-D Gene," Forestry Studies in China, Vol. 8, 2006, pp. 75-81.

[37] Y. Castonguay, P. Nadeau and R. R. Simard, "Effects of Flooding on Carbohydrate and ABA Levels in Roots and Shoots of Alfalfa," Plant Cell and Environment, Vol. 16, No. 6, 1993, pp. 695-702. doi:10.1111/j.1365-3040.1993.tb00488.x

[38] R. E. Sharp, "Interaction with Ethylene, Changing Views on the Role of Abscisic Acid in Root and Shoot Growth Responses to Water Stress," Plant Cell Environment, Vol. 25, No. 2, 2002, pp. 211-222. doi:10.1046/j.1365-3040.2002.00798.x

[39] B. N. Zhai, C. M. Sun, J. R. Wang and S. X. Li, "Effects of Nitrogen Deficiency on the Growth and Development of Winter Wheat Root," Acta Agronomica Sinica, Vol. 29, No. 6, 2003, pp. 913-918.

[40] S. L. Niu, G. M. Jiang, S. Q. Wan, M. Z. Liu, L. M. Gao and Y. G. Li, "Ecophysiological Acclimation to Different Soil Moisture in Plants from a Semi-Arid Sandland," Journal Arid Environments, Vol. 63, No. 2, 2005, pp. $353-$ 365. doi:10.1016/j.jaridenv.2005.03.017

[41] K, Terazawa, Y. Maruyama and Y. Morikawa, "Photosynthetic and Stomatal Responses of Larixkaempferi Seedlings to Short-Term Waterlogging," Ecological Research, Vol. 7, No. 2, 1992, pp. 193-197. doi:10.1007/BF02348500

\section{Abbreviations:}

LN: low nitrogen; $\mathrm{MN}$ : medium nitrogen; $\mathrm{HN}$ : high nitrogen; DAT: days after transplanting cotton seedlings into pots, WW: well-watered; DS: drought-stressed; WL: waterlogged. 